TECHNICAL EQUIVALENCE BETWEEN PERKIN-ELMER DRCe AND ELAN 6000 FOR THE ANALYSIS OF 238U IN URINE BIOASSAY SAMPLES

Carolyn T. Wong, Lori Johnson Collins

September 5, 2007 
This document was prepared as an account of work sponsored by an agency of the United States Government. Neither the United States Government nor the University of California nor any of their employees, makes any warranty, express or implied, or assumes any legal liability or responsibility for the accuracy, completeness, or usefulness of any information, apparatus, product, or process disclosed, or represents that its use would not infringe privately owned rights. Reference herein to any specific commercial product, process, or service by trade name, trademark, manufacturer, or otherwise, does not necessarily constitute or imply its endorsement, recommendation, or favoring by the United States Government or the University of California. The views and opinions of authors expressed herein do not necessarily state or reflect those of the United States Government or the University of California, and shall not be used for advertising or product endorsement purposes.

This work was performed under the auspices of the U.S. Department of Energy by University of California, Lawrence Livermore National Laboratory under Contract W-7405-Eng-48. 


\section{TECHNICAL EQUIVALENCE BETWEEN PERKIN- ELMER DRCe AND ELAN 6000 FOR THE ANALYSIS OF ${ }^{238} \mathrm{U}$ IN URINE BIOASSAY SAMPLES}

Reviewed \& Approved by:

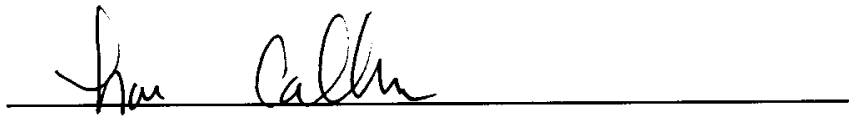

Lori Collins

SPD Quality Assurance Officer

Reviewed \& Approved by:

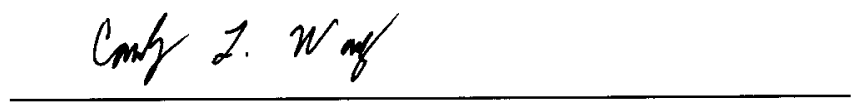

Carolyn T. Wong

Bioassay Laboratory Subject Matter Expert
9/5/07

Date
$9 / 5107$

Date 


\section{Technical Equivalence Between Perkin-Elmer DRCe and Elan 6000 for the Analysis of ${ }^{238} U$ in Urine Bioassay Samples}

The LLNL Bioassay Laboratory recently purchased a Perkin-Elmer DRCe ICP-MS (DRCe) to replace the existing Perkin-Elmer Elan 6000 ICP-MS (Elan 6000) used for the analysis of ${ }^{238} \mathrm{U}$ in urine bioassay samples. In accordance with section 5.7.2 of DOE-STD-1112-98, "The Department of Energy Laboratory Accreditation Program for Radiobioassay", this document demonstrates that the DRCe is technically equivalent to the Elan 6000.

This paper documents: 1) Minor changes made in the procedure to improve the sensitivity; 2) Detection limits for the Elan 6000 and the DRCe; 3) Determination of the measurement uncertainty for the DRCe; and 4) Comparison of results from the DRCe versus the Elan 6000.

\section{Summary of Existing Procedure}

A $1 \mathrm{~mL}$ aliquot of the sample is transferred to an auto sampler tube. Nitric acid and ${ }^{233} \mathrm{U}$ (used as an internal standard) are added to the samples and the samples are digested in a microwave oven. The digested samples are diluted to $10 \mathrm{~mL}$ with deionized water and the ${ }^{238} \mathrm{U}$ concentration is determined by ICP-MS.

The ICP-MS is calibrated with a series of ${ }^{238} \mathrm{U}$ standards. ${ }^{233} \mathrm{U}$ is used as an internal standard to correct for suppression of the signal due to the sample matrix. The Elan 6000 is run in the peakhopping mode with $100 \mathrm{~ms}$ dwell times and 50 sweeps. The total integration time is 5,000 ms. The average of two measurements is used for the determination.

\section{Modifications to the Procedure to Improve the Sensitivity}

In order to reduce the interference from the presence of low levels of ${ }^{238} \mathrm{U}$ and ${ }^{235} \mathrm{U}$ in the ${ }^{233} \mathrm{U}$ internal standard, the amount of internal standard used was reduced from $50 \mathrm{uL}$ to $10 \mathrm{uL}$. No other changes were made in the sample preparation steps.

The existing procedure included calibration standards at $0.005 \mathrm{ug} / \mathrm{L}$ to $0.1 \mathrm{ug} / \mathrm{L}$. In the revised procedure, additional standards at $0.0005 \mathrm{ug} / \mathrm{L}$ and $0.001 \mathrm{ug} / \mathrm{L}$ were added to accommodate lower detection limits. Standards at $0.2 \mathrm{ug} / \mathrm{L}$ and $0.5 \mathrm{ug} / \mathrm{L}$ were also added to increase the dynamic range for the analysis.

The DRCe is run in the peak-hopping mode with $100 \mathrm{~ms}$ dwell times and 100 sweeps. The total integration time is $10,000 \mathrm{~ms}$. The average result for three measurements is used for the determination of the final result. These modifications were made to improve the statistics for the analysis. 
The two instruments are from the same manufacturer and run similar versions of the PerkinElmer Elan software (version 3.3 on the DRCe and 3.0 on the Elan 6000). No changes (other than those indicated above) to the operation of the instrument were required.

Modifications to the data transfer process from the DRCe to the LLNL Bioassay Laboratory Information Management System (BLIMS) database were made so that instrument data is transferred using the local laboratory network rather than using a floppy disk for the data transfer. Modifications were also made in the report to accommodate inclusion of the BLAB identification numbers on the ICP-MS reports.

\section{Experimental}

Blank urine (collected from individuals not occupationally exposed to uranium) were spiked with varying amounts of ${ }^{238} \mathrm{U}$ standard and analyzed as samples using the "Determination of Uranium in Urine by ICP/MS" procedure. Eight replicates at each concentration were prepared separately by four Bioassay Laboratory Analysts (two replicates per Analyst). Each series of spikes were run as separate runs on the DRCe. Results for the urine blanks were used to determine the detection limit. Results for the urine blanks and the spikes were used to determine the measurement uncertainty.

The results for these analyses are summarized in Table 1 . The seventh result for the $0.010 \mathrm{ug} / \mathrm{L}$ spike was determined to be an outlier (see Appendix A) and not used in any of the calculations. The high bias in the analytical results is due to the presence of natural uranium in the urine used to prepare the spikes.

\section{Method Detection Limit (MDL99) for the Elan 6000}

"Method Development of Uranium Analysis in Urine Matrix by ICP-MS" describes the technical basis for the analysis of ${ }^{238} \mathrm{U}$ by ICP-MS on the Elan 6000. Included in this document is the determination of the Method Detection Limit (MDL) and the Reporting Limit (RL). The MDL99, is the minimum concentration of an analyte that in a given matrix can be measured and reported with $99 \%$ confidence that the analyte concentration is greater than zero. This value is equivalent to the Currie $\mathrm{L}_{\mathrm{C}}$ at the $99 \%$ confidence interval. Based on the analysis of ten replicate urine blank samples, the MDL9g was determined to be $0.002 \mathrm{ug} / \mathrm{L}$. A Reporting Limit (RL) of 0.01 ug/L, was derived by multiplying the MDL 99 by five.

\section{Method Detection Limit (MDL99) for the DRCe}

For comparison purposes, the detection limit study described above was repeated on the DRCe. The procedure described in the experimental section of this document, which accounts for interanalyst and inter-run variability, was used for the determination. The original determination performed on the Elan 6000 was determined based on seven replicates prepared by a single 
analyst and analyzed in a single run. We feel that allowing for inter-analyst and inter-run variability provides a more realistic determination of the detection limit.

The MDL99 is calculated as follows:

$$
M D L_{99}=\left(t_{n-1,0.99}\right)(S)
$$

Where:

$\mathrm{t}_{(\mathrm{n}-1,0.99)}=$ Student's $\mathrm{t}$ factor at the $99 \%$ confidence limit for $\mathrm{n}$ replicate values, and

$\mathrm{S}=$ the standard deviation of the $\mathrm{n}$ replicate values

Based on a standard deviation for the eight replicate samples of $0.0011 \mathrm{ug} / \mathrm{L}$ and a Student's t factor of 2.998, the MDL99 is calculated to be $0.0033 \mathrm{ug} / \mathrm{L}$ for the DRCe.

\section{Minimum Detectable Amount (MDA95) and Decision Level (L $\left.{ }_{C 95}\right)$ based on N13.30}

Section 3.4 of N13.30 - "Performance Criteria for Radiobioassay" requires the service laboratory to use methodology presented in N13.30 to determine the $\mathrm{MDA}_{95}$ and the $\mathrm{L}_{\mathrm{C} 95}$. The $\mathrm{MDA}_{95}$ is the minimum detectable amount which provides a $<5 \%$ probability of a Type I error as well as a 5\% probability of a Type II error (as opposed to the MDL or $L_{C}$ which only accounts for Type I errors). Additionally Section 4.3.1.1 requires the use of "appropriate blanks" which should be in the matrix of interest. Thus urine blanks were used for the determination rather than reagent blanks.

The ICP-MS analysis provides a direct readout of the results in ug/L. Thus it is similar to the Uranium by Kinetic Phosphorescence Analysis and the following calculation is based on the example in A.5.13.2 of N13.30. The $\mathrm{MDA}_{95}$ is calculated as follows:

$$
M D A_{95}=(2)\left(t_{n-1,0.95}\right)(S)
$$

Where:

$\mathrm{t}_{(\mathrm{n}-1,0.95)}=$ Student's $\mathrm{t}$ factor at the 95\% confidence limit for $\mathrm{n}$ replicate values, and

$\mathrm{S}=$ the standard deviation of the $\mathrm{n}$ replicate values

Note the Student's t factor is used because only a limited number of replicates were performed for the determination. For large numbers of replicates (well-known background) $(2)\left(t_{(n-1,0.95)}\right)$ approaches 3.29.

Based on a standard deviation for the eight replicate samples of $0.0011 \mathrm{ug} / \mathrm{L}$ and a Student's t factor of 1.895, the $\mathrm{MDA}_{95}$ is calculated to be $0.0042 \mathrm{ug} / \mathrm{L}$. 
The $\mathrm{L}_{\mathrm{C} 95}$ is calculated as follows:

$$
L_{C 95}=\left(t_{n-1,0.95}\right)(S)
$$

Where $\mathrm{t}_{(\mathrm{n}-1,0.95)}$ and $\mathrm{S}$ are defined as above.

Again the Student's t factor is used because only a limited number of replicates were performed for the determination. For large numbers of replicates (well-known background) $t_{(n-1,0.95)}$ approaches 1.645 .

Based on a standard deviation for the eight replicate samples of $0.0011 \mathrm{ug} / \mathrm{L}$ and a Student's t factor of 1.895, the $\mathrm{L}_{\mathrm{C} 95}$ is calculated to be $0.0021 \mathrm{ug} / \mathrm{L}$.

\section{Required Measurement Quality Objectives (per Internal Dosimetry Requirements)}

The "Draft LLNL Technical Basis Manual for Internal Dosimetry” (7/31/07), Appendix B includes an expected $\mathrm{MDA}_{95}$ of $0.01 \mathrm{ug} / \mathrm{L}$ for the analysis of ${ }^{238} \mathrm{U}$ by ICP-MS. The MDA 95 determined above clearly meets this expectation.

\section{Determination of the Measurement Uncertainty for the DRCe}

The combined standard uncertainty (CSU, $1 \sigma$ ) of the analysis is estimated by the standard deviation of the replicate analyses. Based on the data included in Table 1, a plot of the standard deviations versus the average values is included in Figure 1. A linear regression line through all of the points yields a line represented by the equation (note the line displayed in Figure 1 does not appear linear due to the log scale):

$$
\begin{gathered}
\mathrm{CSU}=0.0100\left(\mathrm{ug} / \mathrm{L}{ }^{238} \mathrm{U}\right)+0.0005 \\
\mathrm{R}^{2}=0.9952
\end{gathered}
$$

A visual inspection of the plot and the data indicate that the CSU is a constant value of $1 \%$ above $0.1 \mathrm{ug} / \mathrm{L}$ of ${ }^{238} \mathrm{U}$. Below $0.1 \mathrm{ug} / \mathrm{L}{ }^{238} \mathrm{U}$ the regression line underestimates the standard deviations. Below $0.1 \mathrm{ug} / \mathrm{L}$ of ${ }^{238} \mathrm{U}$ the CSU is best represented by a constant value of 0.0015 (red line on Figure 1). Therefore the CSU shall be calculated as follows:

$$
\begin{array}{ll}
\mathrm{ug} / \mathrm{L}{ }^{238} \mathrm{U}<0.1 \mathrm{ug} / \mathrm{L} & \mathrm{CSU}=0.0015 \mathrm{ug} / \mathrm{L} \\
\mathrm{ug} / \mathrm{L}{ }^{238} \mathrm{U} \geq 0.1 \mathrm{ug} / \mathrm{L} \quad \mathrm{CSU}=0.0100\left(\mathrm{ug} / \mathrm{L}{ }^{238} \mathrm{U}\right)+0.0005
\end{array}
$$

\section{Comparison of Results Between the DRCe and the Elan 6000}

Three batches of samples containing from 35 to 55 samples were analyzed on both the Elan 6000 and the DRCe. Plots of the data comparing the results for the Elan 6000 versus the DRCe are included in Figure 2 through Figure 4. The excellent correlation coefficients $\left(R^{2} \geq 0.9979\right)$ and 
slopes of approximately 1 (0.9893 to 1.0076) demonstrate that the results for the two instruments are equivalent.

Additional comparisons were performed using performance testing samples previously received from ORNL. Results for these comparisons are summarized in Table 2. A two-tailed paired ttest, at the $95 \%$ confidence level, analysis of each of the two sets of data give P values of 0.547 and 0.329 indicating that the results are equivalent.

\section{Summary}

The information presented in this document clearly demonstrates that the new DRCe meets the MQO requirement for the LLNL Internal Dosimetry Program and that analytical results for the new instrument (DRCe) are technically equivalent to the old instrument (Elan 6000). The Lc and $\mathrm{MDA}_{95}$ determined for this procedure of $0.0021 \mathrm{ug} / \mathrm{L}$ and $0.0042 \mathrm{ug} / \mathrm{L}$ are well below the expected detection limit of $0.01 \mathrm{ug} / \mathrm{L}$. Additionally comparisons of the analyses of routine samples and performance testing samples on both the DRCe and the Elan 6000 demonstrate excellent agreement between the two instruments.

\section{References}

1. The Department of Energy Laboratory Accreditation Program for Radiobioassay, DOESTD-1112-98.

2. Determination of Uranium in Urine by ICP/MS, 8/27/2007.

3. Method Development of Uranium Analysis in Urine Matrix by ICP-MS, LLNL-HCD internal document, 2001.

4. N13.30 - Performance Criteria for Radiobioassay.

5. Draft LLNL Technical Basis Manual for Internal Dosimetry, 7/31/07. 
Table 1 - Summary of Spiked Urine Blank Samples on the DRCe

\begin{tabular}{|c|c|c|c|c|c|c|c|c|c|c|}
\hline $\begin{array}{l}\text { Spike Value } \\
\text { (ug/L) }\end{array}$ & $\begin{array}{c}\text { UB } \\
\text { Urine }\end{array}$ & $\begin{array}{l}0.002 \\
\text { Urine }\end{array}$ & $\begin{array}{l}0.005 \\
\text { Urine }\end{array}$ & $\begin{array}{l}0.010 \\
\text { Urine }\end{array}$ & $\begin{array}{l}0.050 \\
\text { Urine }\end{array}$ & $\begin{array}{l}0.200 \\
\text { Urine }\end{array}$ & $\begin{array}{l}0.500 \\
\text { Urine }\end{array}$ & $\begin{array}{l}\mathbf{1 . 0 0 0} \\
\text { Urine }\end{array}$ & $\begin{array}{l}2.000 \\
\text { Urine }\end{array}$ & $\begin{array}{l}\mathbf{5 . 0 0 0} \\
\text { Urine }\end{array}$ \\
\hline & 0.0056 & 0.0106 & 0.0143 & 0.0156 & 0.0552 & 0.2082 & 0.5140 & 1.0121 & 2.0212 & 5.0356 \\
\hline & 0.0055 & 0.0102 & 0.0098 & 0.0150 & 0.0573 & 0.2091 & 0.5112 & 1.0084 & 2.0204 & 5.0295 \\
\hline & 0.0073 & 0.0091 & 0.0128 & 0.0168 & 0.0577 & 0.2062 & 0.5146 & 1.0131 & 2.0447 & 5.0444 \\
\hline & 0.0068 & 0.0087 & 0.0116 & 0.0159 & 0.0569 & 0.2117 & 0.5089 & 1.0202 & 2.0202 & 5.0237 \\
\hline & 0.0071 & 0.0086 & 0.0115 & 0.0172 & 0.0573 & 0.2080 & 0.5043 & 1.0034 & 1.9904 & 4.9849 \\
\hline & 0.0071 & 0.0085 & 0.0119 & 0.0169 & 0.0553 & 0.2082 & 0.5004 & 0.9953 & 1.9821 & 4.9098 \\
\hline & 0.0086 & 0.0107 & 0.0134 & $0.034^{*}$ & 0.0597 & 0.2101 & 0.5026 & 1.0020 & 1.9949 & 4.9962 \\
\hline & 0.0081 & 0.0104 & 0.0138 & 0.0187 & 0.0595 & 0.2086 & 0.5075 & 1.0059 & 1.9995 & 4.9376 \\
\hline $\mathrm{n}$ & 8 & 8 & 8 & 7 & 8 & 8 & 8 & 8 & 8 & 8 \\
\hline Average & 0.0070 & 0.0096 & 0.0124 & 0.0166 & 0.0574 & 0.2088 & 0.5079 & 1.0076 & 2.0092 & 4.9952 \\
\hline stdev (S) & 0.0011 & 0.0010 & 0.0015 & 0.0012 & 0.0017 & 0.0016 & 0.0052 & 0.0077 & 0.0208 & 0.0498 \\
\hline RSD & $15.5 \%$ & $10.0 \%$ & $11.9 \%$ & $7.4 \%$ & $2.9 \%$ & $0.8 \%$ & $1.0 \%$ & $0.8 \%$ & $1.0 \%$ & $1.0 \%$ \\
\hline
\end{tabular}

* Sample result discarded as an outlier (see Appendix A) 
Table 2 - Comparison of Results for the Elan 6000 versus the DRCe (ORNL Samples)

\begin{tabular}{|c|c|c|c|c|c|}
\hline & \multicolumn{2}{|c|}{ BLAB DRCe } & \multicolumn{2}{c|}{ ELAN 6000 } & DRCe \\
\hline $\begin{array}{c}\text { Expected } \\
(\mathrm{ug} / \mathrm{L})\end{array}$ & $\begin{array}{c}\text { Observed } \\
(\mathrm{ug} / \mathrm{L})\end{array}$ & $\%$ Bias & $\begin{array}{c}\text { Observed } \\
\text { (ug/L) }\end{array}$ & $\%$ Bias & \\
\hline 3.04 & 2.980 & $-2.0 \%$ & 3.000 & $-1.3 \%$ & 0.993 \\
\hline 3.04 & 2.970 & $-2.3 \%$ & 3.010 & $-1.0 \%$ & 0.987 \\
\hline 3.04 & 3.070 & $1.0 \%$ & 3.250 & $6.9 \%$ & 0.945 \\
\hline 3.04 & 2.930 & $-3.6 \%$ & 2.750 & $-9.5 \%$ & 1.065 \\
\hline 3.04 & 3.040 & $0.0 \%$ & 3.160 & $3.9 \%$ & 0.962 \\
\hline 3.04 & 3.010 & $-1.0 \%$ & 3.000 & $-1.3 \%$ & 1.003 \\
\hline 3.04 & 3.060 & $0.7 \%$ & 3.040 & $0.0 \%$ & 1.007 \\
\hline 3.04 & 3.150 & $3.6 \%$ & 3.190 & $4.9 \%$ & 0.987 \\
\hline Average & 3.026 & $-0.5 \%$ & 3.050 & $0.3 \%$ & 0.994 \\
\hline STDEV & 0.069 & & 0.155 & & \\
\hline & & & & & \\
\hline 1.02 & 0.937 & $-8.1 \%$ & 0.994 & $-2.5 \%$ & 0.943 \\
\hline 1.02 & 0.959 & $-6.0 \%$ & 0.968 & $-5.1 \%$ & 0.991 \\
\hline 1.02 & 0.970 & $-4.9 \%$ & 1.330 & $30.4 \%$ & 0.729 \\
\hline 1.02 & 0.992 & $-2.7 \%$ & 1.100 & $7.8 \%$ & 0.902 \\
\hline 1.02 & 0.971 & $-4.8 \%$ & 1.040 & $2.0 \%$ & 0.934 \\
\hline 1.02 & 0.981 & $-3.8 \%$ & 1.030 & $1.0 \%$ & 0.952 \\
\hline 1.02 & 0.992 & $-2.7 \%$ & 0.866 & $-15.1 \%$ & 1.145 \\
\hline 1.02 & 0.986 & $-3.3 \%$ & 0.897 & $-12.1 \%$ & 1.099 \\
\hline Average & 0.974 & $-4.6 \%$ & 1.028 & $0.8 \%$ & 0.962 \\
\hline STDEV & 0.019 & & 0.144 & & \\
\hline
\end{tabular}


Figure 1 - $1 \sigma$ Error on DRCe

STDEV of Replicates

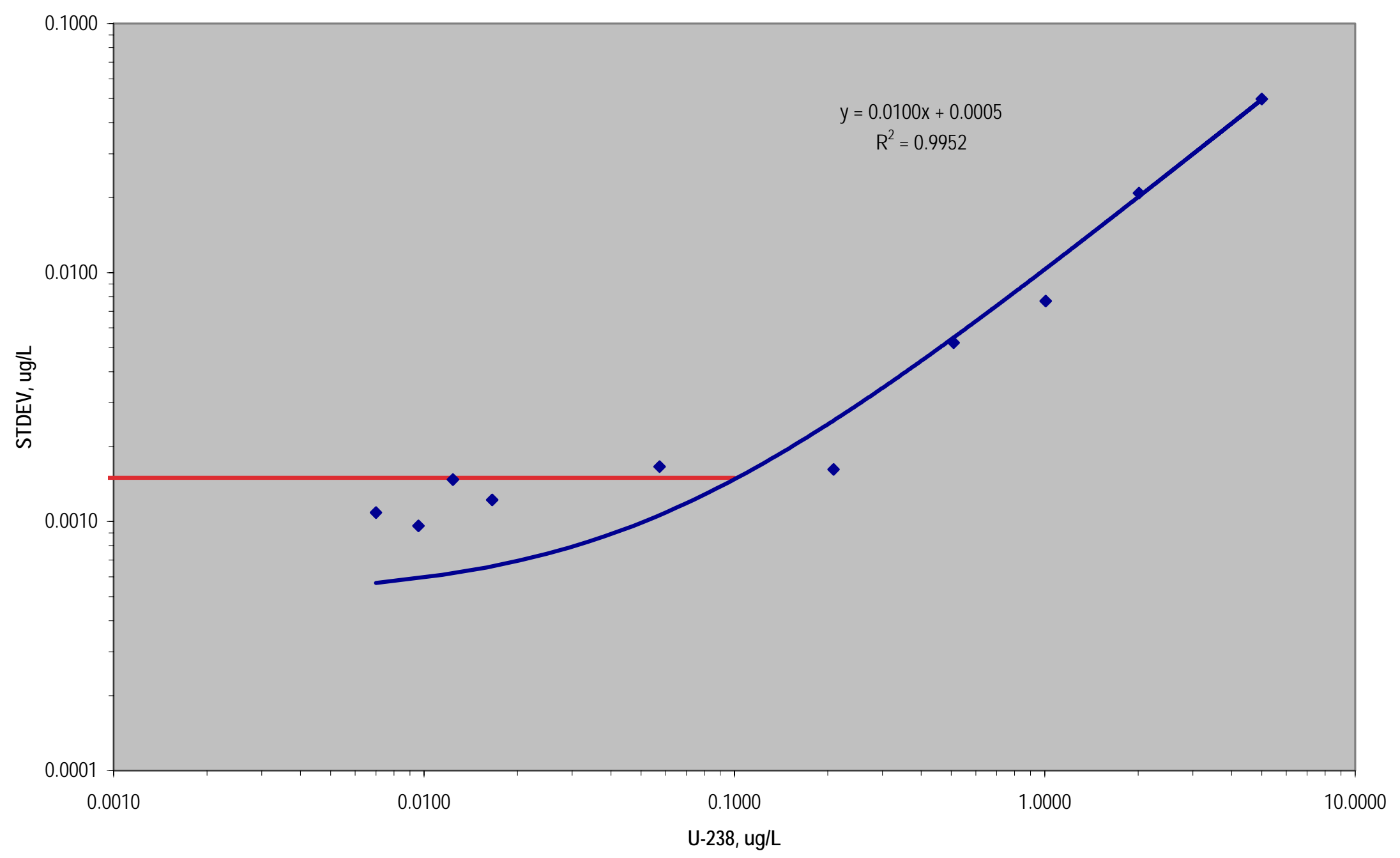

Page 9 of 13 
Figure 2 - Comparison of Results for Elan 6000 versus the DRCe (BLIMS Batch \#102506)

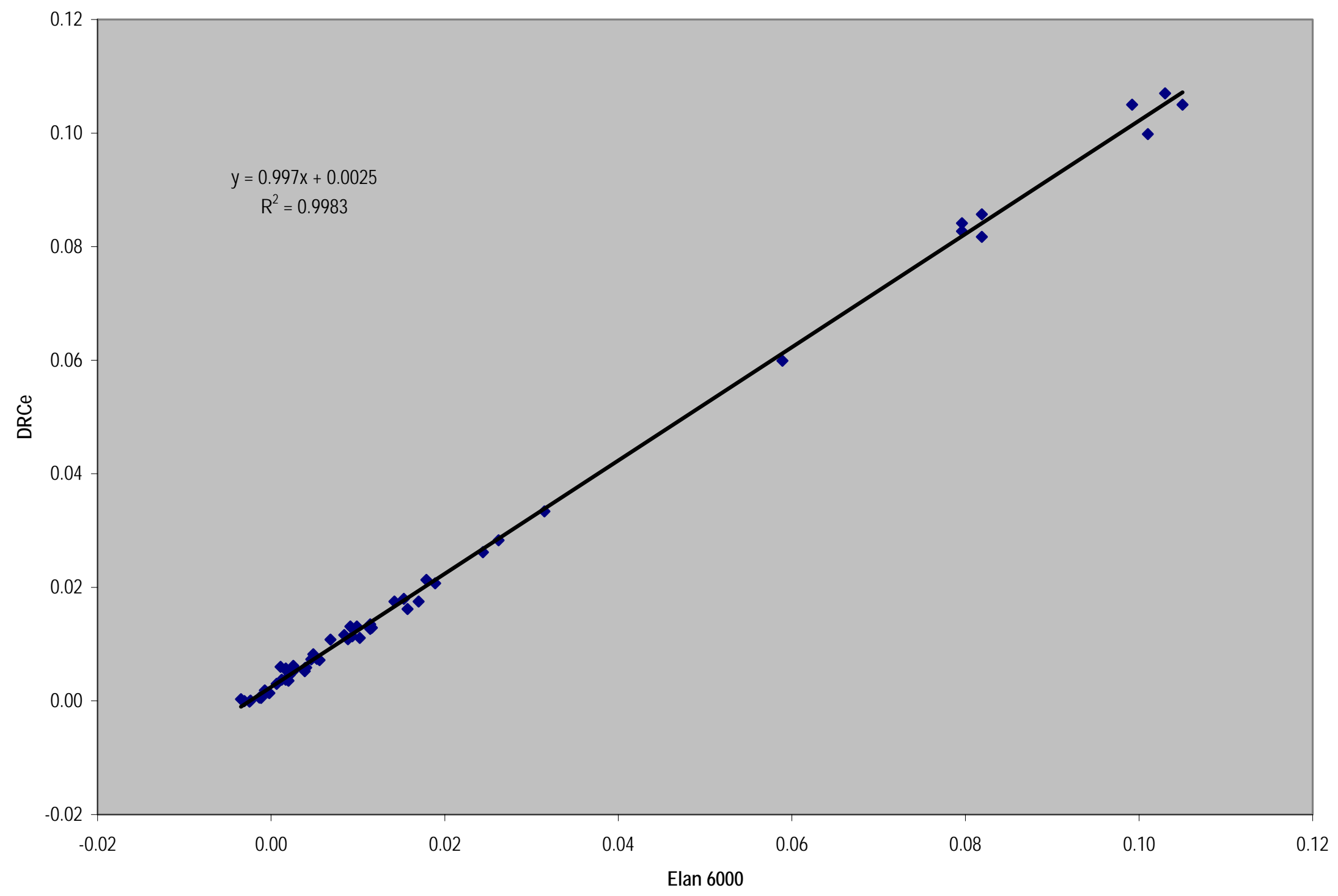

Page 10 of 13 
Figure 3 - Comparison of Results for the Elan 6000 versus the DRCe (BLIMS Batch \#102533)

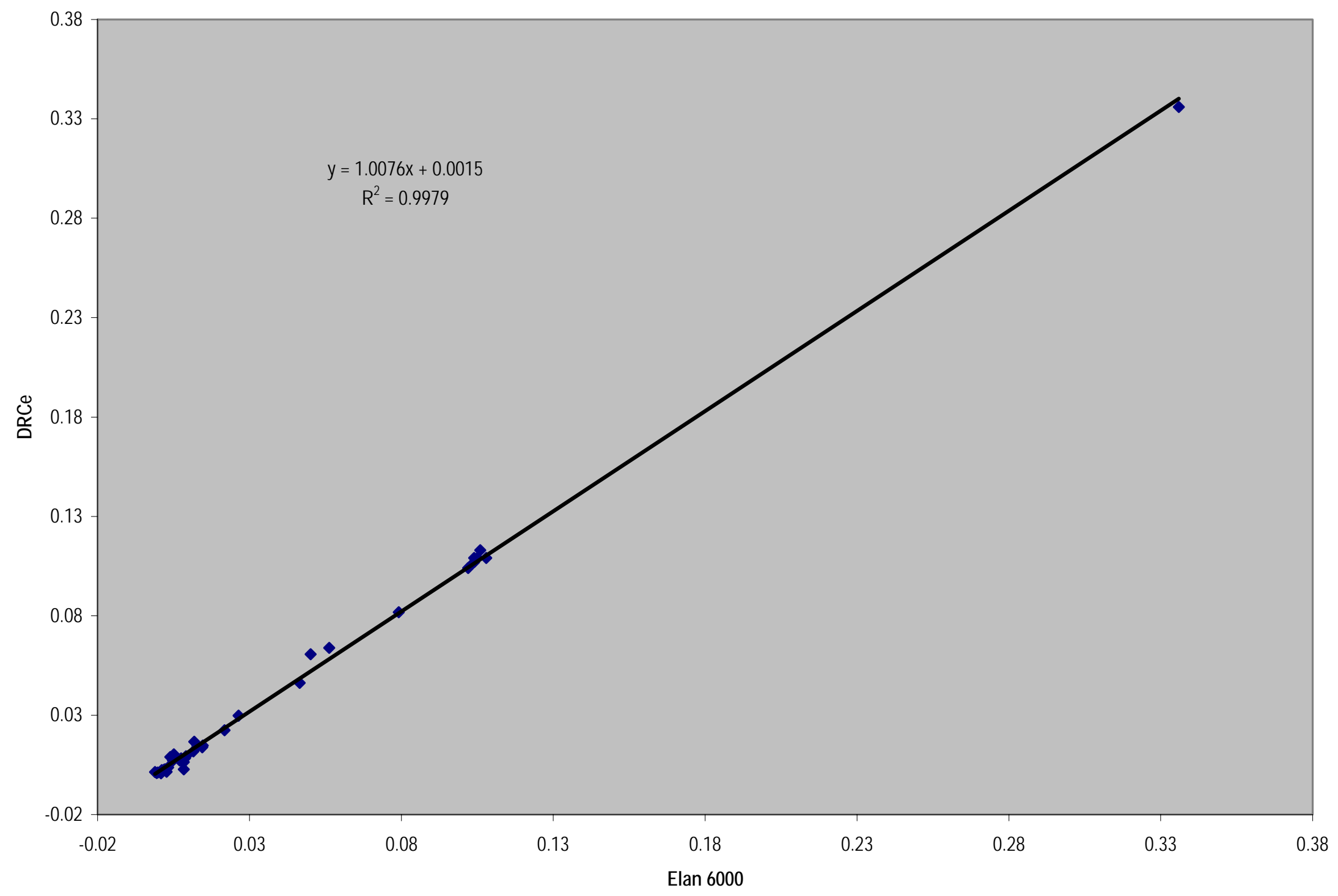

Page 11 of 13 
Figure 4 - Comparison of Results for the Elan 6000 versus the DRCe (BLIMS Batch \#102540)

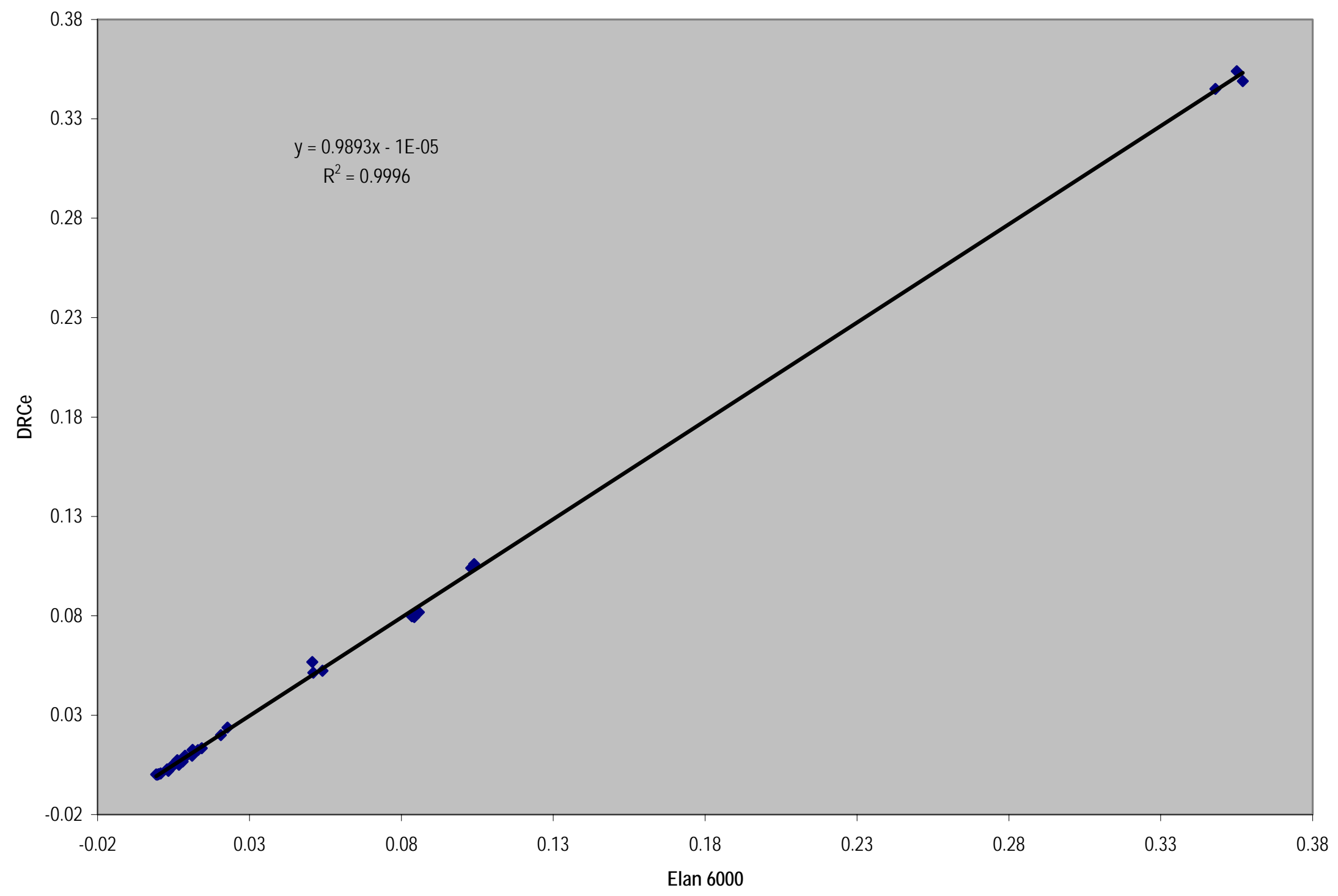

Page 12 of 13 


\title{
Appendix A - Outlier Test
}

Results of outlier test

Page 1 of 1

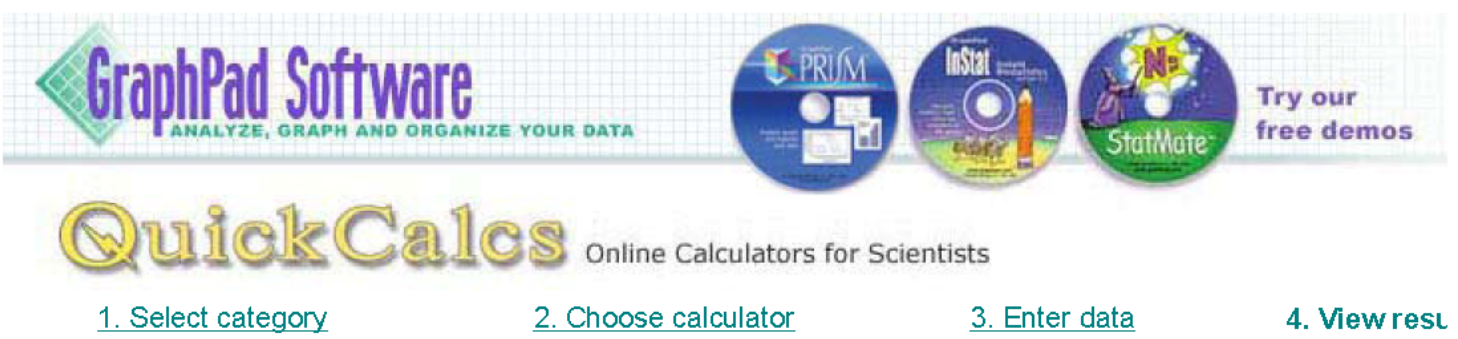

\section{Outlier Results}

This calculator performed Grubbs' test, also called the ESD method (extreme studentized deviate), to detern whether the most extreme value in the list you entered is a signficant outlier from the rest. Unlike some other outlier tests, Grubbs' test only asks whether that one value is an outlier. It is not appropriate to then remove t outlier, and run the test again. Learn more about the principles of outlier detection and exactly how this test i: calculated.

\section{Descriptive Statistics}

\author{
Mean: 0.018762 \\ SD: 0.006260 \\ \# of values: 8 \\ Outlier detected? Yes \\ Significance level: 0.05 (two-sided) \\ Critical value of $Z: 2.13$
}

\section{Your data}

\begin{tabular}{|c|c|c|c|}
\hline Row & Value & $\mathrm{Z}$ & Significant Outlier? \\
\hline 1 & 0.0156 & 0.505205 & \\
\hline 2 & 0.0150 & 0.601054 & \\
\hline 3 & 0.0168 & 0.313507 & \\
\hline 4 & 0.0159 & 0.457280 & \\
\hline 5 & 0.0172 & 0.249607 & \\
\hline 6 & 0.0169 & 0.297532 & \\
\hline 7 & 0.0340 & 2.434170 & Significant outlier. $P<0.05$ \\
\hline 8 & 0.0187 & 0.009984 & \\
\hline
\end{tabular}

All contents copyright (S) 2002 - 2005 by GraphPad Software, Inc. All rights reserved. 